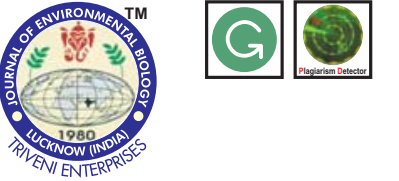

\title{
Effect of sulphur on soil biological properties, residual fertility and yield of aerobic rice grown under aerobic rice-wheat cropping system in Inceptisols
}

Authors Info

A. Ram $^{1 *}$, D. Kumar', S. Babu ${ }^{3}$, D. Prasad and I. Dev ${ }^{4}$

${ }^{1}$ ICAR-Central Agroforestry Research Institute, Jhansi-284 003, India

${ }^{2}$ Division of Agronomy, Indian Agricultural Research Institute, New Delhi-110 012, India

${ }^{3}$ ICAR Rersearch Complex for NEH region, Sikkim Centre, Tadong-737 102, India

${ }^{4}$ Agriculture Research Station, Swami Keshwanand Rajasthan Agricultural University, Sriganganagar-335 001, India

*Corresponding Author Email : ashusirvi84@gmail.com

Key words
Gypsum,
Microbial biomass,
Phosphogypsum,
Rice yield,
Soil fertility
Publication Info
Paper received: 17.02 .2016
Revised received: 08.07 .2016
Re-revised received:09.10.2016
Accepted: 05.11 .2016

\section{Abstract}

Aim: Rice productivity is stagnant or declining due to imbalanced nutrition, including deficiency of sulphur. In India about $44 \%$ soils (out of total cultivated land) is sulphur deficient. Various sources of sulphur fertilizers are available, but gypsum and phosphogypsum can be better options for the farmers. The main aim of this study was to improve the soil fertility, soil microbial properties and rice yields with application of sulphur.

Methodology: The combination of two sulphur sources (gypsum \& phosphogypsum) at two levels i.e., 30 and $60 \mathrm{~kg} \mathrm{ha}^{-1}$ and control (no S) were applied to rice crop and three levels of sulphur (elemental sulphur) i.e., 0,15 and $30 \mathrm{~kg} \mathrm{~S}$ ha ${ }^{-1}$ were applied to succeeding wheat grown under rice-wheat cropping system. Microbial biomass carbon and microbial activities in terms of Fluorescein Diacetate (FDA) hydrolysis, Dehydrogenase and Arylsulphatase activity were estimated in different treatments by standard procedures. Organic carbon, N, P, K and S were estimated for residual fertility after harvest of rice crop. Rice grain yield was recorded at $14 \%$ moisture content.

Results: Direct and residual effect of sulphur application increased the wheat grain and straw yield. Sulphur application increased 8.2 to $12.8 \%$ (microbial biomass carbon), 16.9 to $32.3 \%$ (arylsulphatase activity) and 8.7 to $11.2 \%$ (rice grain yield). Available $\mathrm{N}$ and $\mathrm{P}$ in soil were observed higher in control (no sulphur) than the other sulphur treatments. However, sulphur status after two years of cropping system was improved by 6.4, 12.7, 5.2 and 9.7\% with sulphur application through gypsum @ 30 and 60 kg S ha'; phosphogypsum @ 30 and $60 \mathrm{~kg} \mathrm{Sha}^{-1}$, respectively.

Interpretation: Sulphur is also essential as microbial-S for the micro-organism. Hence, sulphur application increased the microbial biomass carbon and arylsulphatase activity. Application of sulphur through gypsum or phosphogypsumin soil improved the soil microbial properties and sulphur availability. Application of sulphur @ $30 \mathrm{~kg} \mathrm{ha}^{-1}$ through gypsum can increase the rice yield by $10 \%$ over control (no sulphur).

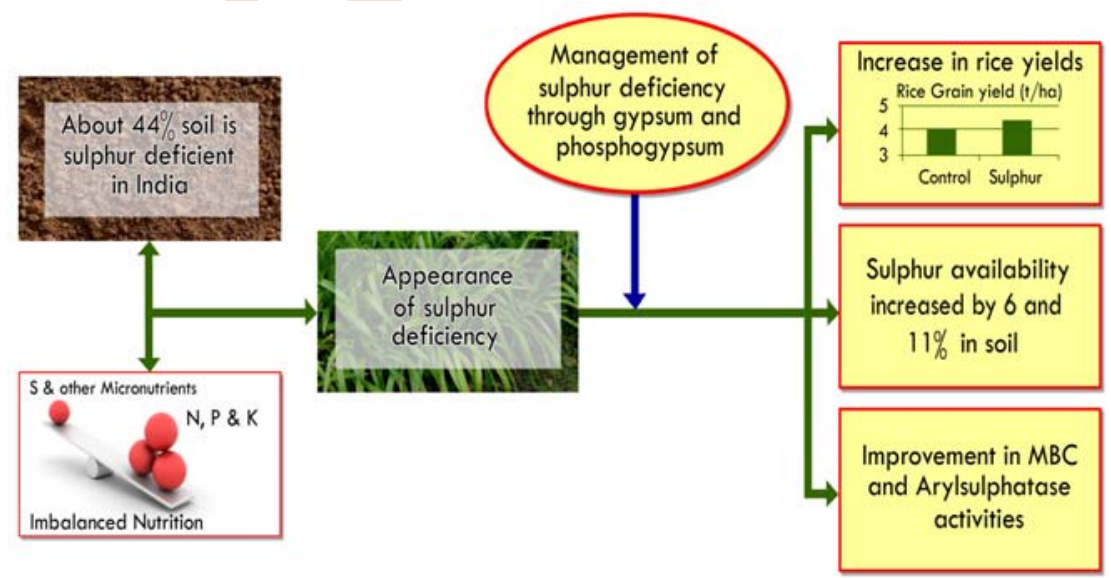




\section{Introduction}

Rice is the staple food not only in India but also in most of the Asian countries, where it is mostly grown under submerged soil conditions and requires more water as compared to other crops. It is estimated that, by 2025 about 15 million ha of dry- and wet-season rice will experience water scarcity (Tuong and Bouman, 2003). In India, majority of rice growing areas like Haryana, Punjab and western Uttar Pradesh are experiencing annual lowering of $1.0 \mathrm{~m}$ water table due to non-judicious use of groundwater (World Bank, 2010). These situations promote the rice farmers and researchers to reduce the water consumption during crop production and enhance the water productivity. Aerobic rice production is a revolutionary way of growing rice in well-drained, unpuddled and unsaturated soils without ponded water in rice field. Besides water scarcity, several other challenges like decreasing soil fertility have also emerged against sustainable production of rice based cropping systems.

Nutrient response of major nutrient has declined due to emergence of multi-nutrient deficiency (Basak et al., 2016). Sulphur is the fourth essential element required for the normal growth of plants, but its deficiency is widespread at least in about $44 \%$ of the $142 \mathrm{~m}$ ha arable land of India (Singh, 2006). A fast decline in available sulphur in soil is chiefly due to higher crop removal by high yielding cultivars; crop intensification; poor replenishment in soil due to use of S-free fertilizers i.e. urea and DAP (Ram et al., 2014b). The requirement of sulphur for aerobic rice varies according to physico-chemical properties of soil. Rice crop remove sulphur @ $3.5 \mathrm{~kg} \mathrm{t}^{-1}$ of rice grain yield (Prasad, 2007). Addition of $\mathrm{N}$ and $\mathrm{P}$ could not change the rice yield in $\mathrm{S}$ deficient soils (Singh et al., 2012). Balanced nutrition not only reduces the dose of fertilizers, but also make changes in soil fertility by enhancing microbial activities (Lupwayi et al., 2001) which have been proposed as indicators of healthy soil (Machulla et al., 2005, Nayak et al., 2011). Microorganisms in soil play an effective role in organic matter decomposition and maintenance of soil fertility. The effect of sulphur on soil microorganisms can be quantified as microbial biomass or as changes in biological activity, e.g. soil respiration and enzyme activities (Ziomek and Koper, 2010).

There are many sources of sulphur fertilizers available in India, but gypsum is the most common due to its cheaper prices and ease in availability. Phosphogypsum, another cheaper source of sulphur, is a byproduct of phosphate fertilizer is gaining attention and market acceptance as sulphur source (Nayak et al., 2011). As of now, not much scientific studies and their documentation have been made so far on the effect of sulphur on soil microbial activities, yields and soil fertility in aerobic rice fields under rice-wheat cropping system. Therefore, considering all these facts, a field experiment was conducted with an aim to improve rice yield, residual fertility and soil microbial activities with application of sulphur through various sources at different levels.

\section{Materials and Methods}

Experimental details : A field experiment was carried out during rainy seasons (kharif; June-September) at the research farm of Indian Agricultural Research Institute, New Delhi $\left(28^{\circ} 38^{\prime} \mathrm{N}\right.$, $77^{\circ} 09^{\prime} \mathrm{E}$ and $228.6 \mathrm{~m}$ above mean sea level). The mean annual rainfall of the area is $650 \mathrm{~mm}$ and more than $80 \%$ generally occurs during the SW-monsoon season (July-September) with mean annual evaporation of $850 \mathrm{~mm}$. The total rainfall received during crop season was $898.6 \mathrm{~mm}$ (2010) and $574.3 \mathrm{~mm}$ (2011).

The experimental soil was sandy clay loam in texture (sand $51.4 \%$, silt $22.2 \%$ and clay $26.4 \%$ ) with $7.5 \mathrm{pH}$ (1:2.5 soil and water ratio) and medium in organic $\mathrm{C}\left(5.4 \mathrm{~g} \mathrm{~kg} \mathrm{~g}^{-1}\right.$ soil) and low in available $\mathrm{N}$ (176 kg ha $\left.{ }^{-1}\right)$; available $\mathrm{P}\left(14.6 \mathrm{~kg} \mathrm{ha}^{-1}\right)$, available $\mathrm{K}$ $\left(275 \mathrm{~kg} \mathrm{ha}^{-1}\right)$ and available $S\left(16.5 \mathrm{~kg} \mathrm{ha}^{-1}\right)$.

Two sources of sulphur i.e. gypsum and phosphogypsum were taken for rice crop. Before application, both the sources were analyzed for S, Ca and P content. It was ensured that all the treatments received equal nutrients except sulphur. The experiment was laid out in Randomized Block Design with five treatments comprising of combinations of two $S$ sources [Gypsum (G) \& phosphogypsum (PG)] with two levels i.e. 30 \& 60 $\mathrm{kg} \mathrm{ha}^{-1}$, and control (no S) with three replications. Wheat crop was taken after rice in which each main plot was split into three sub plots and 0,15 and $30 \mathrm{~kg} \mathrm{~S}^{-1}$ was applied through elemental sulphur. Recommended doses of N, P, K, Zn were applied as 150, $26.2,33.2,5.0 \mathrm{~kg} \mathrm{ha}^{-1}$, respectively along with $S$ treatments every year. The $1 / 3^{\text {rd }} \mathrm{N}$ and full dose of $\mathrm{P}, \mathrm{K}, \mathrm{Zn}$ and $\mathrm{S}$ were applied as a basal dose at the time of sowing. The remaining $N$ was top dressed in two equal splits at tillering and panicle initiation stages. Rice hybrid 'PRH 10' was sown (40 kg ha') in rows, with a row to row spacing of $20 \mathrm{~cm}$. Rice was grown as per recommended agronomic practices. Wheat variety DBW 17 was grown in rabi season of 2010-11 and 2011-12.

Determination of microbial parameters : Soil samples were taken randomly from each plot (from 0-15 cm depth) at panicle initiation stage for estimation of microbial parameters. The soil samples were dried and moisture content adjusted to $50 \%$ of water holding capacity and, visible plant material was removed. Microbial biomass carbon in soil was estimated by the method described by Nunan et al. (1998). Microbial activity in terms of fluorescein diacetate (FDA) hydrolysis was measured by Green et al. (2006) procedure. Dehydrogenase and Arylsulphatase activity were estimated following the method of Casida et al. (1964) and Tabatabai and Bremner (1970), respectively.

Yield and residual soil fertility : After harvesting, threshing, cleaning and drying, the grain yield of aerobic rice was recorded at $14 \%$ moisture. Straw yield was obtained by subtracting grain yield from the total biomass yield. For estimation of residual fertility, soil samples $(0-15 \mathrm{~cm}$ depth) were collected before the 
beginning of field experiment and after harvest of rice during both the years of study and analyzed for organic carbon by wet digestion method (Walkley and Black, 1934), available nitrogen by alkaline permanganate $\left(\mathrm{KMnO}_{4}\right)$ procedure (Subbiah and Asija, 1956), available phosphorus by the method of Olsen et al. (1954) available potassium by flame photometer (Prasad et al., 2006) and available sulphur by Williams and Steinberg (1959) method.

Statistical analysis: Analysis of variance (ANOVA) was performed with the PROC MIXED procedure of SAS/STAT software (SAS Institute, 1999) to determine the effects of sulphur on soil biological properties, residual fertility and yields of aerobic rice grown under rice-wheat cropping sequence. Least significant difference (LSD) at $5 \%$ level of probability and $P$ values were used to examine differences among the treatment means.

\section{Results and Discussion}

As perusal of data presented in Table 1 on microbial biomass carbon ( $\mu \mathrm{g} \mathrm{MBC} \mathrm{g}^{-1}$ soil), dehydrogenase activity ( $\mu \mathrm{g}$ TPF $g^{-1}$ soil $d^{-1}$ ), FDA hydrolysis ( $\mu$ g fluorescein $\mathrm{g}^{-1}$ soil $\mathrm{h}^{-1}$ ) and arylsulphatase activity ( $\mu \mathrm{g} \mathrm{pNP} \mathrm{g}^{-1}$ soil $\mathrm{h}^{-1}$ ) showed that sulphur application had a significant effect on microbial biomass carbon as compared to control (no sulphur) during both the years of experimentation. Averaged across two years, application of sulphur through gypsum @ 30 and $60 \mathrm{~kg} \mathrm{~S} \mathrm{ha}^{-1}$; phosphogypsum

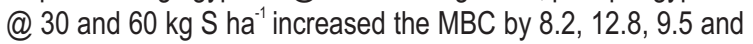
$12.0 \%$, respectively over control. Though highest values of microbial biomass carbon (264 and $272 \mu \mathrm{g} \mathrm{MBC} \mathrm{g}^{-1}$ soil) were recorded with $60 \mathrm{~kg} \mathrm{~S} \mathrm{ha}^{-1}$ applied through gypsum during 2010 and 2011, respectively, however significant response of $S$ was found only up to $30 \mathrm{~kg} \mathrm{~S} \mathrm{ha}^{-1}$. A increase in microbial biomass carbon may be attributed to increase in microbial population for mineralization of gypsum or phosphogypsum. Microbial biomass is the driving force not only for carbon cycle, but also for other nutrients viz., N, P and S (Banerjee and Chapman, 1996). Microbial biomass carbon is directly related to microbial sulphur, hence sulphur application positively influenced the microbial biomass carbon in sulphur deficient soil (Lupwayi et al., 2001).

Dehydrogenase activities in soil remain unchanged with sulphur application during first year of experimentation, while during second year; significant improvement in dehydrogenase activity was observed in all the sulphur treatments (Table1). Though highest dehydrogenase activity $\left(61.2 \mu \mathrm{g} \mathrm{TPF} \mathrm{g}^{-1}\right.$ soil $\left.^{-1}\right)$ was recorded with $60 \mathrm{~kg}$ sulphur ha- ${ }^{-1}$ applied through gypsum, but all the treatment combinations of sulphur remained at par during second year. The positive correlation of dehydrogenase activity with bio-available nutrients has also been reported by German et al. (2011) and Basak et al. (2016). Different biotic and abiotic factors such as incubation time and temperature, pre-incubation, soil amelioration, soil aeration and moisture content have significant effects on dehydrogenase activity in soil (Kumar et al., 2013). As observed in dehydrogenase activity, no significant effect of $S$ was also noticed on FDA hydrolysis ( $\mu$ g fluorescein $\mathrm{g}^{-1}$ soil hr ${ }^{-1}$ ) during first year of study (Table 1). During second year, significantly higher rate of FDA hydrolysis $\left(2.35 \mu \mathrm{g}\right.$ fluorescein $\mathrm{g}^{-1}$ soil hr ${ }^{-1}$ ) was measured with $60 \mathrm{~kg} \mathrm{~S} \mathrm{ha}^{-1}$ applied through gypsum. FDA activity is a sensitive and non-specific tool for representing the hydrolytic activity of soil micro-organisms. Candida et al. (2012) reported that an increase in enzyme activity is related to the organic manure application and amendments.

Table 1: Effect of sources and levels of sulphur on microbial activities in the soils of aerobic rice (at panicle initiation stage)

\begin{tabular}{|c|c|c|c|c|c|c|c|c|}
\hline \multirow[t]{2}{*}{ Treatments } & \multicolumn{2}{|c|}{$\begin{array}{c}\text { MBC } \\
\left(\mu g^{-1} \text { soil) }\right.\end{array}$} & \multicolumn{2}{|c|}{$\begin{array}{l}\text { Dehydrogenase activity } \\
\left(\mu \mathrm{g} T P F g^{-1} \text { soil d }{ }^{-1}\right)\end{array}$} & \multicolumn{2}{|c|}{$\begin{array}{l}\text { FDA hydrolysis }(\mu \mathrm{g} \\
\text { fluorescein } \mathrm{g}^{-1} \text { soil }^{-1} \text { ) }\end{array}$} & \multicolumn{2}{|c|}{$\begin{array}{l}\text { Arylsulphatase activity } \\
\left(\mu \mathrm{g} \mathrm{pNP} \mathrm{g}{ }^{-1} \text { soil }^{-1}\right)\end{array}$} \\
\hline & 2010 & 2011 & 2010 & 2011 & 2010 & 2011 & 2010 & 2011 \\
\hline \multicolumn{9}{|l|}{ Direct effect } \\
\hline Control & 233 & 242 & 56.5 & 53.7 & 2.11 & 2.10 & 46.0 & 44.7 \\
\hline $\mathrm{G} @ \mathrm{~S}_{30}$ & 250 & 264 & 61.3 & 59.3 & 2.31 & 2.21 & 52.6 & 54.3 \\
\hline $\mathrm{G} @ \mathrm{~S}_{60}$ & 264 & 272 & 59.4 & 61.2 & 2.34 & 2.35 & 61.3 & 58.7 \\
\hline PG@S & 258 & 262 & 63.9 & 60.6 & 2.36 & 2.20 & 52.9 & 53.1 \\
\hline$P G @ S_{60}$ & 261 & 271 & 64.4 & 60.3 & 2.38 & 2.29 & 59.0 & 56.3 \\
\hline SEm \pm & 5.0 & 3.0 & 2.66 & 1.2 & 0.09 & 0.04 & 1.8 & 1.3 \\
\hline $\mathrm{CD}(P=0.05)$ & 17.0 & 11.0 & NS & 3.9 & NS & 0.13 & 5.9 & 4.1 \\
\hline \multicolumn{9}{|l|}{ Residual effect } \\
\hline $\mathrm{S}_{0}$ & - & 258 & - & 58.0 & - & 2.22 & - & 52.2 \\
\hline $\mathrm{S}_{15}$ & - & 261 & - & 59.3 & - & 2.22 & - & 52.8 \\
\hline$S_{30}^{15}$ & - & 267 & - & 59.9 & - & 2.25 & - & 55.3 \\
\hline SEm \pm & - & 5.0 & - & 1.3 & - & 0.05 & - & 1.2 \\
\hline$C D(P=0.05)$ & - & NS & - & NS & - & NS & - & NS \\
\hline
\end{tabular}

MBC-Microbial Biomass Carbon; FDA-Fluorescein Diacetate; pNP-p-nitrophenol; TPF-Triphenylformazan; G-Gypsum; PG-Phosphogypsum; NS-Non significant; $\mathrm{S}_{0,15,30,60}-$ Sulphur @0,15,30 and $60 \mathrm{~kg} \mathrm{ha}^{-1}$ 
Table 2 : Effect of sources and levels of sulphur on residual fertility in soil after harvest of aerobic rice

\begin{tabular}{|c|c|c|c|c|c|c|c|c|}
\hline \multirow[t]{2}{*}{ Treatments } & \multicolumn{2}{|c|}{$\begin{array}{l}\text { Soil organic carbon } \\
\text { (g kg-1 soil) }\end{array}$} & \multicolumn{2}{|c|}{$\begin{array}{c}\text { Available N } \\
\left(\mathrm{kg} \mathrm{ha}^{-1}\right)\end{array}$} & \multicolumn{2}{|c|}{$\begin{array}{c}\text { Available P } \\
\left(\mathrm{kg} \mathrm{ha}^{-1}\right)\end{array}$} & \multicolumn{2}{|c|}{$\begin{array}{c}\text { Available K } \\
\left(\mathrm{kg} \mathrm{ha}^{-1}\right)\end{array}$} \\
\hline & 2010 & 2011 & 2010 & 2011 & 2010 & 2011 & 2010 & 2011 \\
\hline $\begin{array}{l}\text { Initial value } \\
\text { Direct effect }\end{array}$ & 0.54 & & 176 & & 14.6 & & 275 & \\
\hline Control & 5.4 & 5.1 & 176 & 183 & 14.6 & 13.5 & 277 & 272 \\
\hline $\mathrm{G} @ \mathrm{~S}_{30}$ & 5.3 & 5.2 & 172 & 175 & 13.1 & 12.3 & 275 & 263 \\
\hline $\mathrm{G} @ \mathrm{~S}_{60}$ & 5.4 & 5.4 & 168 & 171 & 13.8 & 11.8 & 271 & 256 \\
\hline$P G @ S_{30}$ & 5.2 & 5.2 & 173 & 178 & 13.2 & 12.4 & 272 & 266 \\
\hline PG@S & 5.2 & 5.3 & 170 & 176 & 13.1 & 11.9 & 271 & 257 \\
\hline SEm \pm & 0.1 & 0.1 & 1.6 & 2.0 & 0.4 & 0.3 & 3.0 & 4.0 \\
\hline $\mathrm{CD}(P=0.05)$ & NS & NS & 5.0 & 6.0 & 1.2 & 0.9 & NS & NS \\
\hline Residual effec & & & & & & & & \\
\hline $\mathrm{S}_{0}$ & - & 5.2 & - & 178 & - & 12.6 & - & 265 \\
\hline $\mathrm{S}_{15}$ & - & 5.1 & - & 175 & - & 12.2 & - & 263 \\
\hline $\mathrm{S}_{30}$ & - & 5.1 & - & 176 & - & 12.3 & - & 262 \\
\hline SEm \pm & - & 0.1 & - & 1.0 & - & 0.1 & & 3.0 \\
\hline $\mathrm{CD}(P=0.05)$ & - & NS & - & NS & - & NS & - & NS \\
\hline
\end{tabular}

G-Gypsum; PG-Phosphogypsum; NS-Non significant; $S_{0,15,30,60}-$ Sulphur @ 0, 15, 30 and $60 \mathrm{~kg} \mathrm{ha}^{-1}$

Table 3: Effect of sources and levels of sulphur on yields and harvest index of aerobic rice and wheat grown under rice-wheat cropping sequence

\begin{tabular}{|c|c|c|c|c|c|c|c|c|c|c|c|c|}
\hline \multirow[t]{3}{*}{ Treatments } & \multicolumn{6}{|c|}{ Rice } & \multicolumn{6}{|c|}{ Wheat } \\
\hline & \multicolumn{2}{|c|}{ Grain yield $\left(t_{\text {ha }}{ }^{-1}\right)$} & \multicolumn{2}{|c|}{ Straw yield (tha $\left.{ }^{-1}\right)$} & \multicolumn{2}{|c|}{$\mathrm{HI}(\%)$} & \multicolumn{2}{|c|}{ Grain yield $\left(\mathrm{tha}^{-1}\right)$} & \multicolumn{2}{|c|}{ Straw yield (t ha $\left.{ }^{-1}\right)$} & \multicolumn{2}{|c|}{$\mathrm{HI}(\%)$} \\
\hline & 2010 & 2011 & 2010 & 2010 & 2011 & 2010 & 2011 & 2010 & 2011 & 2010 & 2011 & 2010 \\
\hline \multicolumn{7}{|l|}{ Direct effect } & \multicolumn{4}{|c|}{ Residual effect } & & \\
\hline Control & 3.92 & 4.10 & 6.96 & 7.10 & 36.0 & 36.6 & 4.62 & 4.72 & 6.81 & 7.13 & 40.4 & 39.8 \\
\hline $\mathrm{G} @ \mathrm{~S}_{30}$ & 4.25 & 4.54 & 7.43 & 7.92 & 36.3 & 36.5 & 4.84 & 4.99 & 7.09 & 7.53 & 40.6 & 39.9 \\
\hline $\mathrm{G} @ \mathrm{~S}_{60}$ & 4.32 & 4.61 & 7.47 & 8.01 & 36.6 & 36.5 & 5.09 & 5.15 & 7.55 & 7.73 & 40.2 & 40.0 \\
\hline$P G @ S_{30}$ & 4.22 & 4.50 & 7.37 & 7.86 & 36.4 & 36.4 & 4.79 & 4.98 & 7.11 & 7.64 & 40.3 & 39.5 \\
\hline$P G @ S_{60}$ & 4.30 & 4.59 & 7.43 & 8.03 & 36.7 & 36.4 & 5.02 & 5.10 & 7.43 & 7.70 & 40.4 & 39.9 \\
\hline SEm \pm & 0.08 & 0.06 & 0.07 & 0.12 & 0.3 & 0.3 & 0.07 & 0.05 & 0.07 & 0.12 & 0.2 & 0.1 \\
\hline $\mathrm{CD}(P=0.05)$ & 0.26 & 0.20 & 0.21 & 0.38 & NS & NS & 0.23 & 0.17 & 0.23 & 0.38 & NS & NS \\
\hline \multicolumn{7}{|c|}{ Residual effect } & \multicolumn{4}{|c|}{ Direct effect } & & \\
\hline $\mathrm{S}_{0}$ & - & 4.43 & - & 7.73 & - & 36.5 & 4.56 & 4.68 & 6.74 & 7.07 & 40.4 & 39.8 \\
\hline $\mathrm{S}_{15}$ & - & 4.47 & - & 7.80 & - & 36.5 & 4.93 & 5.09 & 7.30 & 7.74 & 40.3 & 39.7 \\
\hline $\mathrm{S}_{30}$ & - & 4.50 & - & 7.83 & - & 36.5 & 5.12 & 5.19 & 7.56 & 7.83 & 40.4 & 39.9 \\
\hline SEm \pm & - & 0.05 & - & 0.11 & - & 0.2 & 0.06 & 0.06 & 0.11 & 0.10 & 0.3 & 0.2 \\
\hline $\mathrm{CD}(\mathrm{P}=0.05)$ & - & NS & - & NS & - & NS & 0.17 & 0.16 & 0.31 & 0.30 & NS & NS \\
\hline
\end{tabular}

G-Gypsum; PG-Phosphogypsum; NS-Non significant; $\mathrm{S}_{0,15,30,60}$-Sulphur @ 0, 15,30 and 60 kg ha'; ;I- Harvest index

Arylsulphatase activity in soil of aerobic rice field increased significantly with S application (Table 1). Among all the $S$ treatments, application of $60 \mathrm{~kg} \mathrm{~S} \mathrm{ha}^{-1}$ through gypsum resulted in significantly higher activity of arylsulphatase $(61.3$ and $58.7 \mu \mathrm{g}$ pNP g ${ }^{-1}$ soil $\mathrm{h}^{-1}$ ) as compared to other treatments, except $60 \mathrm{~kg} \mathrm{~S}$ $\mathrm{ha}^{-1}$ applied through phosphogypsum during 2010 and 2011, respectively. Averaged over two years, application of sulphur through gypsum @ 30 and 60 kg S ha ${ }^{-1} ;$ phosphogypsum @ 30 and $60 \mathrm{~kg} \mathrm{~S}^{-1}$ increased the arylsulphatase activity by 17.9 , $32.3,16.9$ and $27.1 \%$, respectively over control. No significant difference was observed in soil biological properties at same level of sulphur application. Arylsulphatase is mainly synthesized by bacteria and fungi and identified as a key enzyme for $\mathrm{S}$ mineralization (Vong et al., 2008) which plays an important role in the sulphur cycling (Chen et al., 2001). Increase in arylsulphatase activity with sulphur application up to $112 \mathrm{~kg} \mathrm{ha}^{-1}$ has been reported by Ye et al. (2010). The residual effects of elemental sulphur applied to preceding wheat in 2010 were non-significant on microbial biomass carbon, dehydrogenase activity, FDA hydrolysis and arylsulphatase activity in soils during succeeding 
Table 4: Correlation matrix between microbial activities, available sulphur and rice grain yield

\begin{tabular}{lllllll}
\hline & MBC & $\begin{array}{l}\text { Dehydrogenase } \\
\text { activity }\end{array}$ & FDAhydrolysis & $\begin{array}{l}\text { Arylsulphatase } \\
\text { activity }\end{array}$ & $\begin{array}{l}\text { Available } \\
\text { sulphur }\end{array}$ & Grain yield \\
\hline MBC & 1 & & & & & \\
Dehydrogenase activity & 0.578 & 1 & 1 & & & \\
FDAhydrolysis & 0.677 & 0.873 & 0.845 & 1 & 1 & 1 \\
Arylsulphatase activity & 0.847 & 0.675 & 0.551 & 0.794 & 0.962 & 1 \\
Available sulphur & 0.951 & 0.490 & 0.433 & 0.664 & & \\
Grain yield & 0.932 & 0.401 & & & & \\
\hline
\end{tabular}

rice in 2011.

Organic carbon content in soil did not change with the application of sulphur during both the years of study (Table 2). Available nitrogen in soil was significantly higher (176 and $183 \mathrm{~kg}$ ha $^{-1}$ ) in control than with $60 \mathrm{~kg} \mathrm{~S} \mathrm{ha-1} \mathrm{during} 2010$ and 2011. Furthermore, highest available $\mathrm{P}\left(\mathrm{kg} \mathrm{ha}^{-1}\right)$ was observed in control, which was significantly higher over all the sulphur treatments, except $60 \mathrm{~kg} \mathrm{~S} \mathrm{ha}^{-1}$ applied through gypsum during 2010. No significant difference was observed on available $P$ amongst all the sulphur treatments. The high available $\mathrm{N}$ and $\mathrm{P}$ in control (no sulphur and recommended dose of NPK) might be due to lesser uptake of $\mathrm{N}$ and $\mathrm{P}$ because of less biomass (grain + straw yield) productions as compared to sulphur treatments. Irrespective of sources and levels, application of sulphur in rice did not show any substantial effect on available $\mathrm{K}$ in soil after harvest of rice crop during both the years of study (Table 2). This might be due to sufficient level of native $\mathrm{K}$ in soil. Application of $\mathrm{S}$ significantly increased its availability in soil after harvest of aerobic rice (Fig. 1). After two years of cropping, the available sulphur content in soil was exhausted by $11 \%$ under control, whereas it was improved by $6.4,12.7,5.2$ and $9.7 \%$ sulphur application through gypsum @ 30 and 60 kg S ha'; phosphogypsum @ 30 and $60 \mathrm{~kg} \mathrm{~S} \mathrm{ha-1}$, respectively. Though highest amount of available $S\left(17.9\right.$ and $\left.19.3 \mathrm{~kg} \mathrm{ha}^{-1}\right)$ in soil was found with the application of $60 \mathrm{~kg} \mathrm{~S}^{-1} \mathrm{~h}^{-1}$ through gypsum during 2010 and 2011, respectively, however significant effect was found

ロInitial value घControl घGypsum @ S30 ₫Gypsum @ S60 •Phosphgypsum @ S30 •Phosphgypsum @ S60

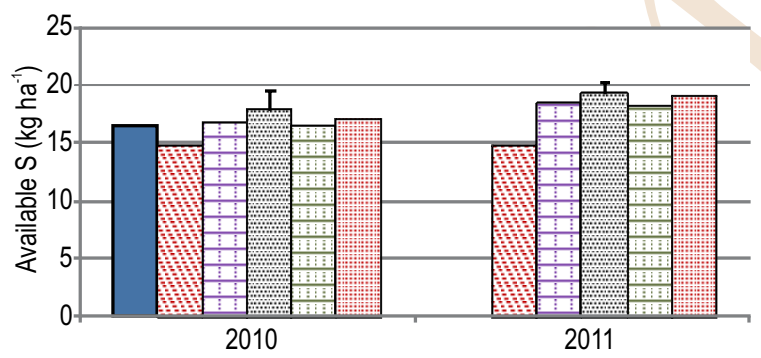

Fig. 1 : Effect of sources and levels of sulphur on available $S\left(\mathrm{~kg} \mathrm{ha}^{-1}\right)$ in soil after harvest of aerobic rice only upto $30 \mathrm{~kg} \mathrm{~S} \mathrm{ha}^{-1}$. The increase in available $S$ in soil is due to increasing amount of added S in S deficient soil (Jena and Kabi, 2012; Singh et al., 2012; Gupta and Jain, 2008; Deshbhratar et al., 2010). The significant residual effect of sulphur applied to preceding wheat was not observed on available $\mathrm{N}, \mathrm{P}, \mathrm{K}$ and $\mathrm{S}$ in soil after harvest of succeeding rice.

Average grain yield of aerobic rice increased from $4.01 \mathrm{t}$ $\mathrm{ha}^{-1}$ in control to $4.47 \mathrm{t} \mathrm{ha}^{-1}$ with $60 \mathrm{~kg} \mathrm{~S} \mathrm{ha}^{-1}$ applied through gypsum (Table 3). However, response of $S$ was observed only up to $30 \mathrm{~kg} \mathrm{~S} \mathrm{ha}^{-1}$. The average data (two years) showed that $\mathrm{S}$ application through gypsum @ 30 and 60 kg S ha'; phosphogypsum @ 30 and $60 \mathrm{~kg} \mathrm{~S} \mathrm{ha}^{-1}$ increased the grain yield of rice by $9.5,11.2,8.7$ and $10.7 \%$, respectively over control. Corresponding values for straw yield were 5.1, 6.0, 4.2 and 5.9\%, respectively. Sulphur applied to wheat did not show any significant residual influence on grain and straw yields of rice. Sulphur application did not affect the harvest index significantly during both the years. Application of sulphur to soil increases its availability in soil (Fig. 1; Ram et al., 2014a; Palsaniya and Ahlawat, 2009), which might have improved the crop growth (Jaggi and Raina, 2008). As evident from the data presented in Table 1 implies that $S$ application significantly and positively increased microbial activities (MBC and Arylsulphatase). The soil microbial activities showed good correlation with the rice grain yield (Fig. 2; Table 4), which might have resulted in better crop growth and yield (Hatfield et al., 2015).

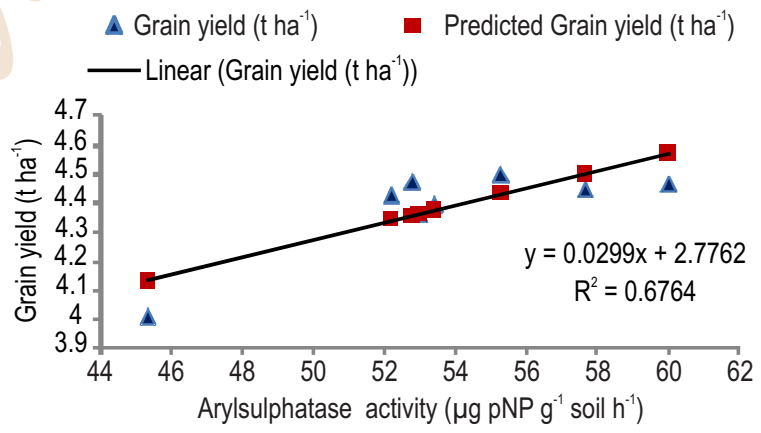

Fig. 2 : Relationship between Arylsulphatase activity and grain yield of aerobic rice 
Application of elemental sulphur @ 15 and $30 \mathrm{~kg} \mathrm{~S} \mathrm{ha}^{-1}$ increased the average grain yield of wheat by 390 and $535 \mathrm{~kg} \mathrm{ha}^{-1}$ respectively, over control (no sulphur). The corresponding values for straw yield were 615 and $790 \mathrm{~kg} \mathrm{ha}^{-1}$, respectively. However during second year of the study, significant response of sulphur application was observed only upto $15 \mathrm{~kg} \mathrm{~S} \mathrm{ha}^{-1}$. Sulphur application @ $60 \mathrm{~kg} \mathrm{ha}^{-1}$ to preceding rice had a significant residual effect on grain yield of wheat during both the years, while significant residual effect of $30 \mathrm{~kg} \mathrm{~S} \mathrm{ha}^{-1}$ applied to preceding rice was observed only during 2011-12. Similar trend was observed in straw yield. Effect of sulphur on harvest index of wheat was nonsignificant. A marked improvement in the productivity of wheat with residual sulphur could be ascribed to enhanced sulphur availability in soil as sulphur applied to preceding crop (rice) was not fully used by the crop leading to residual effect (Palsaniya and Ahlawat, 2009).

From the two years of field study, it can be concluded that application of $S$ through gypsum or phosphogypsum improve the soil biological properties and crop productivity. On an average 10 per cent yield of rice and wheat can be enhanced by sulphur application in sulphur deficient soils. Application of $30 \mathrm{~kg} \mathrm{~S} \mathrm{ha}^{-1}$ with gypsum or phosphogypsum showed as good result as with $60 \mathrm{~kg} \mathrm{~S}^{-1}$ on yields of aerobic rice. Sulphur availability can be increased with $11 \%$ with application of $60 \mathrm{~kg} \mathrm{Sha}^{-1}$.

\section{Acknowledgments}

Authors are thankful to the Indian Council of Agricultural Research, Division of Agronomy, IARI New Delhi for providing opportunity and necessary facilities to conduct this study. Authors are equally grateful to the Department of Science and Technology, Government of India for financial support during the period of study.

\section{References}

Banerjee, M.R. and S.J. Chapman: The significance of microbial biomass sulphur in soil. Biol. Fert. Soils, 22, 116-125(1996).

Basak, N, A. Datta, T. Mitran, B. Mandal and P.K. Mani: Impact of organic and mineral inputs onto soil biological and metabolic activities under long-term rice-wheat cropping system in sub-tropical Indian Inceptisols. J. Environ. Biol., 37, 83-89 (2016).

Candida, O., M. de la L. Mora, R. Demanet, G. Briceño and G. Palma: Effect of liquid cow manure amendment on dimethenamid persistence in a volcanic soil. J. Soil Sci. Plant Nutr.,12, 153-163 (2012).

Casida, L.E.Jr., D.A. Klein and T. Santoro: Soil dehydrogenase activity. Soil Sci., 93, 371-376 (1964).

Chen, C.R., L.M. Condron, M.R. Davis and R.R. Scherlock: Effects of land-use change from grassland to forest on soil sulfur and arylsulfatase activity in New Zealand. Australian J. Soil Res., 39, 749-757 (2001).

Deshbhratar, P.B., P.K. Singh, A.P. Jambhulkar and D.S. Ramteke: Effect of sulphur and phosphorus on yield, quality and nutrient status of pigeonpea (Cajanus cajan). J. Environ. Biol., 31, 933-937 (2010).
German, D.P., M.N. Weintraub, A.S. Grandy, C.L. Lauber, Z.L. Rinkes and S.D. Allison: Optimization of hydrolytic and oxidative enzyme methods for ecosystem studies. Soil Biol. Biochem., 43, 1387-1397 (2011).

Green, V.S., D.E. Ctott and M. Diack: Assay of fluorescein diacetate hydrolytic activity-optimization of soil samples. Soil Biol. Biochem., 38, 693-701 (2006).

Gupta, A.K. and N.K. Jain: Sulphur fertilization in a pearl millet (Pennisetum glaucum)-Indian mustard (Brassica juncea) cropping system. Arch. Agron. Soil Sci., 54, 533-539 (2008).

Hatfield, J.L. and C.L. Walthall: Soil biological fertility: Foundation for the next revolution in agriculture? Commun. Soil Sci. Plant Anal., 46, 753-762 (2015).

Jaggi, R.C. and S.K. Raina: Direct, residual and direct + residual effects of sulphur in garlic (Allium sativum) - maize (Zea mays) cropping sequence. J. Environ. Biol., 29, 85-88 (2008).

Jena, D. and S. Kabi: Effect of gromor sulphur bentonite sulphur pastilles on yield and nutrient uptake by hybrid rice-potato-green gram cropping system in an Inceptisol. Int. Res. J. Agric. Sci. Soil Sci., 2, 179-187 (2012).

Kumar, S., S. Chaudhuri and S.K. Maiti: Soil dehydrogenase enzyme activity in natural and mine soil. A review. Middle-East J. Scient. Res., 13, 898-906 (2013).

Lupwayi, N.Z., M.A. Monreal, G.W. Clayton, C.A. Grant, A.M. Johnston and W.A. Rice: Soil microbial biomass and diversity respond to tillage and sulphur fertilizers. Cana. J. Soil Sci., 81, 577-589 (2001).

Machulla, G., M.A. Bruns and K.M. Scow: Microbial properties of mine spoil materials in the initial stages of soil development. Soil Sci. Soc. Am. J., 69, 1069-1077 (2005).

Nayak, S., C.S.K. Mishra, B.C. Guru and M. Rath: Effect of phosphogypsum amendment on soil physico-chemical properties, microbial load and enzyme activities. J. Environ. Biol., 32, 613-617 (2011).

Nunan, N., M.A. Morgan and M. Herlihy: Ultraviolet absorbance $(280 \mathrm{~nm})$ of compounds released from soil during chloroform fumigation as an estimate of the microbial biomass. Soil Biol. Biochem., 30, 1599-1603 (1998).

Olsen, S.R., C.V. Cole, F.S. Watanabe and L. Dean: Estimation of available phosphorus in soil by extraction with sodium carbonate. U.S.D.A., Washington, Conc. 933 (1954).

Palsaniya, D.R. and I.P.S. Ahlawat: Sulphur management in pigeonpea (Cajanus cajan)-wheat (Triticum aestivum) cropping system. Indian J. Agron., 4, 272-277 (2009).

Prasad, R., Y.S. Shivay, D. Kumar and S.N. Sharma: Learning by doing exercise in soil fertility- A practical manual for soil fertility, Division of Agronomy, IARI, New Delhi (2006).

Prasad, R.: Crop Nutrition-Principles and Practices. New Vishal Publications, New Delhi, p. 127 (2007).

Ram, A., D. Kumar and A. Anand: Direct and residual effect of sulphur on productivity, protein content and nutrient uptake in wheat under aerobic rice-wheat cropping system. Indian J. Fert., 10, 50-55 (2014a).

Ram, A., D. Kumar, N. Singh and A. Anand: Effect of sulphur on growth, productivity and economics of aerobic rice (Oryza sativa). Indian J. Agron., 59, 404-409 (2014b).

SAS Institute: SAS System Version 8. SAS Institute, Cary, NC (1999).

Singh, A.K., M.K. Meena and A. Upadhyaya: Effect of sulphur and zinc on rice performance and nutrient dynamics in plants and soil of IndoGangetic plains. J. Agric. Sci., 4, 162-170 (2012). 
Singh, M.V.: Micro and secondary nutrients and pollutant elements research in India. AICRP on Micronutrients, IISS, Bhopal, pp. 4-98 (2006).

Subbiah, B.V. and G.L. Asija: A rapid procedure for assessment of available nitrogen in rice soils. Curr. Sci., 25, 259-260 (1956).

Tabatabai, M.A. and J.M. Bremner: Arylsulfatase activity of soils. Soil Sci. Soc. Am. Proc., 34, 225-229 (1970).

Tuong, T.P. and B.A.M. Bouman: Rice production in water-scarce environments. In: Water productivity in agriculture: Limits and opportunities for improvement (Eds.: J.W. Kijne, R. Barker and D. Molden). CABI Publishing, Wallingford, pp. 53-67 (2003).

Vong, P.C., S. Piutti, S.S. Deschaumes, E. Benizri and A. Guckert: Sulphur immobilization and arylsulphatase activity in two calcareous arable and fallow soils as affected by glucose additions. Geoderma, 148, 79-84 (2008).

Walkley, A.J. and I.A. Black: An examination of the Degtjareff method for determination of soil organic matter and a proposed modification of the chronic acid titration method. Soil Sci., 37, 29-38 (1934).

Williams, C.H. and A. Steinberg: Soil sulphur fractions and chemical indices of available sulphur in some Australian soils. Australian J. Agric. Res., 10, 340-352 (1959).

World Bank: Deep wells and Prudence: Towards Pragmatic Action for Addressing Groundwater Overexploitation in India, Report 51676, The International Bank for Reconstruction and Development, Washington DC: The World Bank (http://siteresources. worldbank.org/INDIAEXTN/Resources/295583-1268190137195/ Deep Wells Ground Water March2010.pdf) (2010).

Ye, R., A.L. Wright, W.H. Orem and J.M. McCray: Sulfur distribution and transformations in Everglades agricultural area soil as influenced by sulfur amendment. Soil Sci., 175, 263-269 (2010).

Ziomek, A.S. and J. Koper: Changes in the content of sulphate sulphur and arylsulphatase activity in soil under potato caused by fertilization. J. Element., 15, 171-176 (2010). 